\title{
Determining Benefits from B2B e-Commerce: A Strategic Approach ${ }^{1}$
}

George Tanewski. Monash University. Australia.

George.Tanewski@BusEco.monash.edu.au

Philip A. Collier. University of Melbourne. Australia.

pcollier@unimelb.edu.au

Stewart A. Leech. University of Melbourne. Australia.

saleech@unimelb.edu.au

\begin{abstract}
A request from a powerful customer to exchange information electronically is an important external stimulus to the business strategy of a supplier. Prior research indicates that sub-optimal benefits, if any, are the typical result of such a stimulus. In this research, B2B ecommerce alignment between business strategy and IT strategy is proposed as a determinant of enhanced business benefits from electronic information exchange. A multiple case study approach in the Australian automotive industry is used to examine this proposition. As more electronic information is exchanged using a range of electronic modes, thus creating complex interorganizational systems, this research provides insights for suppliers about how to achieve greater benefits from B2B e-commerce.
\end{abstract}

Key words: B2B e-commerce, IT Strategy, Strategic Alignment.

\footnotetext{
1 We are very grateful to Mr Stewart Leslie, Director Causeway Consulting Pty Ltd, Fellow of the Department of Accounting and Business Information Systems University of Melbourne, and previously partner with KPMG, for his assistance as a consultant to this project. We are also grateful to the OEM and the five tier 1 suppliers that informed this research. This research was funded by the Faculty of Business and Economics Research Grant, Monash University and by the Faculty of Commerce and Economics Research Grant, The University of Melbourne. We gratefully acknowledge this financial support.
} 


\section{INTRODUCTION}

B2B e-commerce is concerned with "systems and processes that support the flow of information between organizations as it occurs in procurement; manufacturing; research and development; sales; and distribution of goods, information and services" (Gebauer and Shaw, 2002). In this paper, B2B ecommerce systems and processes include Web-based B2B portals, electronic infot ${ }^{\circ}$ ation exchange using EDI and XML-based languages over proprietary valueadded networks or secure connections over the Internet.

Impetus for the adoption of B2B e-commerce is widespread in many countries. Taking Australia as an example, both the Federal and State Governments have ecommerce development policies and resources, which are wide-ranging and provide numerous case studies ${ }^{2}$, initial funding assistance and discussion of business benefits. For example, EDAG Future is one of the businesses that have received support to develop B2B e-commerce in Australia ${ }^{3}$. Additionally, it is well documented that large hub firms are able to exercise power over their tier 1 (direct) suppliers (spoke firms), with an estimated $80 \%$ to $90 \%$ of tier 1 suppliers receiving or using $\mathrm{EDI}^{4}$ in Australia. The exercise of customer power is an important impetus for EDI adoption in $75 \%$ or more firms (Premkumar and Ramamurthy, 1995; Khananchi and Sutton, 2001).

Two issues documented in the EDAG Future case illustrate the motivation for this research:

- the revenue and cost analysis treats e-commerce as separate from the existing business; and

- EDAG Future considered that "e-commerce was essential to remain competitive".

This illustrates a non-integrated stance with respect to B2B e-commerce by EDAG Future which is a supplier (or spoke) in the automotive industry. The automotive manufacturers (original equipment manufacturers-hereafter referred to as OEMs) are the hubs that strongly encouraging their tier 1 suppliers to adopt e-commerce. Typically, suppliers have complied reluctantly in a minimal fashion, citing the need to "remain competitive" as their primary justification.

\footnotetext{
http://www.noie.gov.au/projects/ebusiness/advancing/case_studies.htm http://www.noie.gov.au/publications/NOIE/eBusiness/e-proc/cs_edag.htm http://www.noie.gov.au/publications/NOIE/ITOL_CS/Auto/index.htm
} 
Research that has examined the benefits created by e-commerce investments has found that integration of electronic information ${ }^{5}$ with the rest of the business is important. Even then, the OEMs can appropriate the benefits that arise from more efficient transactions (Subramani, 2002). Suppliers are able to retain value that is derived by creating knowledge about the marketplace, operating environment and the customer relationship from electronic information exchanged with their customers (Subramani, 2002). These insights are especially important in the context of annual cost reduction targets that are specified by the OEMs ${ }^{6}$.

In common with many IT investments, establishing the value that has been derived from successful adoption of B2B e-commerce is problematic. While different strategies are legitimate as discussed above, this study draws on prior research concerning the benefits of strategic alignment together with prior empirical work on the association between strategic alignment and business value. We specialise this prior research to the context of $\mathrm{B} 2 \mathrm{~B}$ e-commerce and introduce the construct of B2B e-commerce alignment within the firm and with aspects of the customer environment. We propose that this is a determinant of different business benefits for a tier 1 supplier.

This proposition is examined using a multiple case study research method. This method seeks to obtain rich information from tier 1 suppliers about their business and IT strategies in the context of customer encouragement to adopt $\mathrm{B} 2 \mathrm{~B}$ e-commerce. In particular, the level of $\mathrm{B} 2 \mathrm{~B}$ e-commerce alignment is expected to be associated with the mode of $\mathrm{B} 2 \mathrm{~B}$ e-commerce adoption. The results indicate relatively limited attention to IT and related matters amongst tier 1 suppliers, which potentially exposes them to difficulties in creating and assessing potential benefits from adoption of $\mathrm{B} 2 \mathrm{~B}$ e-commerce.

This paper is organized as follows: section 2 contains a description of the theory relevant to this research and the research propositions; section 3 describes the multiple case study method; section 4 discusses the results; section 5 some implications for practice and a final section includes conclusions and limitations.

\footnotetext{
This is high depth, in the terms of Masseti and Zmud (1996).

6 As recorded in Subramani (2002) and anecdotally in conversations with representatives of the supplier companies in the automotive industry in Australia.
} 


\section{BACKGROUND THEORY AND RESEARCH PROPOSITIONS}

B2B e-commerce has the potential to contribute to firm efficiency in execution of market exchanges ${ }^{7}$ (or transaction contracts) and/or firm effectiveness through the ability to participate in a strategic alliance ${ }^{8}$ that maybe focused on time-based competitive advantage. As such, insights about B2B e-commerce arise from the perspectives of transaction cost economics (TCE) and the resource-based view (RBV) of the firm. These lead to a consideration of firm strategy and in particular strategic alignment within the firm. Prior empirical research that builds on these perspectives leads to a model of $\mathrm{B} 2 \mathrm{~B}$ e-commerce alignment that is proposed to be associated with different levels of business benefit.

\subsection{Transaction cost economics (TCE)}

A central argument of a transaction cost perspective is that the organization of economic activities at the firm level is driven by the minimization of not only production costs, but also of the associated transaction costs, which "include all search and information costs, as well as the costs of monitoring and enforcing contractual performance" (Robins, 1987: 69). The choice of transaction type depends on several factors: relationship-specific asset (or resource) specificity, the frequency of the transaction, parties' interests in the transaction, the difficulty of assessing the performance of the transaction, and ambiguity and uncertainty surrounding the transaction (Williamson, 1981).

Asset specificity is a key dimension in the transaction cost perspective as it impacts heavily on the choice of governance mechanisms. For transactions where asset specificity is low, a market-exchange contract between parties is employed and relationship costs are relatively low. As asset specificity increases, more complex contracts are written with numerous contingency clauses to reduce the fear of opportunism ${ }^{9}$. Thus as asset specificity increases, so do transaction costs.

\footnotetext{
Williamson (1985) argues that all economic phenomena are coordinated by market exchanges, that is, goods and services are transacted through some contracting mechanism.

8 We define strategic alliances as "voluntary arrangements between firms to share resources, coordinate joint promotions, production facilities, or develop new products or technologies". (Park, Mezias and Song. 2003)

9 In the limit, vertical integration is suggested (Heide and John, 1988).
} 
Improvements in inter-firm cooperation tend to rely upon transaction or relationship-specific investments (Williamson, 1985). For example, coordination of production facilities through a Just-in-Time (JIT) supply arrangement requires investment in improved inter- and intra-organizational information processing capabilities, which in-turn can help to monitor complex contingency clauses in the supply contract and thus control opportunism (Zaheer and Venkatraman, 1994).

While transaction cost economics provides an explanation of the economic benefits of $\mathrm{B} 2 \mathrm{~B}$ e-commerce by focusing on the cost dimension, it fails to take into account how a firm's resources and capabilities can best be developed and deployed in the search for improved efficiency and effectiveness. Moreover, to fully understand B2B e-commerce activity requires insights of not only the interdependence of production and exchange relations, but how appropriate business strategies and strategic alignment within and outside the organisation enhance firm efficiency and effectiveness. It is important to consider this interdependence because firms are both a collectivity of transactions and a bundle of resources, and it is strategy and the extent of alignment among the firm's strategy, processes and infrastructure that influence how its resources interact with the transaction and how the firm chooses to govern these resources and transactions. To provide a more complete understanding of the relationship among production, exchange relations, and efficiency and effectiveness we now turn to the resourcebased view of the firm.

\subsection{Resource-based view of the firm (RBV)}

In contrast to TCE which focuses on minimizing cost in the context of potential opportunism, RBV focuses on maximising value by combining and using resources available to a firm. When a firm produces consistently superior returns, competitors will seek to either imitate these high performing resources or develop substitute resources to produce similar benefits (Dierickx and Cool, 1989). Hence, Barney (1991) emphasises the notion that valuable resources must also be non-substitutable by having one or more of the following four characteristics:

- they are accumulated over time through learning, experience, firm-specific knowledge, or trained proficiency in a skill (time compression diseconomies);

- they are inherently unique or were initially acquired under nonreplicable conditions (first-mover advantages);

- the value of a resource is inextricably linked to the presence of another complementary resource (embeddedness of resources); 
- the connection between a firm's resource portfolio and its performance is unclear (causal ambiguity) (Barney, 1991; Dierickx and Cool, 1989).

Intangible firm resources (e.g., competencies, tacit knowledge, social relations) tend to be scarce and relatively difficult to imitate (Barney, 1991, 2001). In contrast, tangible resources such as IT infrastructure and production processes are relatively easy to imitate and are less likely to provide competitive advantage. However, Clemons and Row's (1991) "strategic necessity hypothesis" proposes that IT creates advantage by leveraging or exploiting complementary human and business resources. More generally, the strategic management literature (e.g., Wernerfelt, 1984) proposes that a firm's resources are fundamental drivers of both performance and competitive advantage. These linkages are similarly articulated by Prahalad and Hamel (1990) and Ulrich and Lake (1991), who highlight the strategic importance of identifying, managing and leveraging "core competencies".

Thus a resource-based approach to strategy formulation involves a continuous iterative process of determining and assessing the strengths and weaknesses of the firm's resources (Grant, 1991). This approach also takes into account how resources interact with transactions and how the firm chooses to govern these resources and transactions. While both tangible and intangible resources are simultaneously appraised for their rent-generating potential (Grant, 1991: 115), strategies are primarily formulated to deal with and potentially counteract shifts in the environment which can erode the value of resources and undermine the firm's competitiveness.

Consistent with this approach, a tier 1 supplier that is strongly encouraging to adopt e-commerce by an OEM would consider this in light of its current resources, both tangible and intangible. Considerations such as the degree of embeddedness, potential value and imitability can all inform strategy development. Hence strategy not only plays an important role in responding to the competitive environment, it also influences decisions regarding allocation of firm resources and the alignment of different configurations within the firm (Das and Teng, 2000).

\subsection{Strategy and strategic alignment}

Firms can adopt different types of strategic orientations in their attempts to achieve competitive advantage (for example, Porter, 1990; Miles and Snow, 1978). Some authors (for example, Croteau and Bergeron, 2001; Venkatraman, 1989; Zahra and Covin, 1993) show that various dimensions of strategy are positively associated with performance. However, it is not always easy to classify a strategy within a typology (Croteau and Bergeron, 2001). Indeed an indicator of value is 
not the existence of strategy, but rather the strategic alignment of the various domains within the firm (Parnell et al., 1996).

A specific type of alignment that has been studied widely is that between business and information technology strategy. Teo and King (1996) found a positive association between planning, integration and organizational performance, suggesting that greater integration between business planning and IT planning supports a firm's business strategies more effectively. Chan et al. (1997) found that the level of alignment between business and IT strategy is a better predictor of business performance than a business strategy or IT strategy orientation alone. Cragg, King and Hussin (2002) showed that the level of alignment is also a significant indicator of performance in smaller companies. However, alignment must not become a singular goal. Tallon and Kraemer (2003) have found evidence for an alignment paradox, with moderate levels of alignment being associated with the optimum business value.

\subsection{B2B e-commerce}

B2B e-commerce is concerned with "systems and processes that support the flow of information between organizations as it occurs in procurement; manufacturing; research and development; sales; and distribution of goods, information and services" (Gebauer and Shaw, 2002). As such, B2B e-commerce relies on relationship-specific resources in two or more organizations that create the capability for inter-organization electronic information exchange. Prima facie, this information exchange is primarily for the purpose of transactions, but can also be used for broader coordination and cooperation.

Most relevant prior research concerning B2B e-commerce focuses on EDI. From the mid 1990s onwards Internet and Web technologies have underpinned a variety of alternatives to EDI for B2B e-commerce and inter-organization coordination (den Hengst and Sol, 2002). The Internet is more accessible and cheaper to use than the virtual private networks traditionally required to use EDI. However, this has led to an increase in the number of different methods that can be used for B2B e-commerce, many of which are actual or de facto standards. This creates the prospect that multiple hubs will request that a supplier firm uses different B2B e-commerce standards for different customers. Swatman et al. $(1994)^{10}$ propose a four-stage model of technical EDI adoption. The minimum

\footnotetext{
10 Tuunainen (1998) and the depth dimension of Massetti and Zmud (1996) also discusses evolution paths in similar terms.
} 
form of adoption is a manual "rip-and-read" (Lauer, 2000) approach, where an EDI terminal is installed to print and originate EDI messages. From a TCE perspective, this terminal is a specific resource for a specific relationship, which has low embeddedness (RBV). Synchronous integration of EDI messages with internal business information systems, perhaps after in-flight translation, is the most mature form of EDI adoption. Khananchi and Sutton (2001, table 14) report that only $3.9 \%$ of (mostly) SME spoke firms achieved synchronous integration of externally sourced electronic information by early 1998. From a TCE perspective, synchronous integration may create a resource of more general use, especially if there are multiple hub firms, that is highly embedded with other resources in the supplier firm (RBV).

Prekumar and Ramamurthy (1995) and Prekumar, Ramamurthy and Crum (1997) examine the strategic decisions to adopt or not adopt EDI. Top management support and larger firms emerge as strong determinants of proactive adoption and this is associated with higher levels of EDI integration (Iskandar, Kurokawa and LeBlanc, 2001). Competitive pressure and customer power/support is associated with reactive adopters where integration of EDI is low initially, but increases gradually over time (Bergeron and Raymond, 1997). However, one year after EDI adoption, the reactive suppliers used fewer message type ${ }^{11}$ than the committed suppliers, possibly because of fears about disclosing proprietary information (Hart and Saunders, 1998).

Hub firms typically enjoy more tangible benefits compared with the intangible benefits typically reported by spoke firms ${ }^{12}$ (Reekers and Smithson, 1996; Sriram et al., 2000). Bergeron and Raymond (1997) also found that organizational support for EDI is positively associated with benefits from EDI. In the absence of organizational support, their longitudinal study demonstrated that imposition of EDI is negatively associated with benefits initially, but over time these benefits increase, a result that is confirmed by Sriram et al. (2000). These benefits include efficiency gains and some improved work practices such as time-based competitive advantage, for example Sequential Part Delivery for In-Line Vehicle Sequencing systems $^{13}$ (Mukhopadhyay, Kekre and Kalathur, 1995; Riggins and Mukhopadhyay, 1994; Reekers and Smithson, 1996).

\footnotetext{
11 The diversity dimension of Massetti and Zmud (1996).

12 Hubs are reported to perceive EDI to increase productivity or save on manpower, while spoke firms see benefits in terms of enhanced customer service or remaining competitive.

13 http://www.insequence.com/
} 
Chatfield and Yetton (2000) introduce a concept of EDI embeddedness ${ }^{14}$ as a basis for examining levels of inter-organisational cooperation. The theory of embeddedness suggests that embedded inter-firm relationships rely on exchange of sensitive information, joint problem solving and trust. Low-level embeddedness is defined in terms of inter-firm alignment only in the IT domain; moderate-level embeddedness adds alignment in the strategic domain; while high-level alignment relies on social ties between individuals in the firms. Strategic payoff for hub firms is highly correlated with EDI embeddedness for the six case studies considered (Chatfield and Yetton, 2000). For example, Honda in Japan exhibits high-level EDI embeddedness for high strategic payoff, while Ford in the USA exhibits low-level EDI embeddedness with its suppliers and has achieved low strategic payoff.

Shams and Wheeler (2003), in criticising prior definitions of alignment between business and IT strategy, seek to define alignment in terms of informational dimensions of organizational behaviour. These dimensions are syntactic alignment (coordinated procedures), semantic alignment (shared understanding) and pragmatic alignment (convergent intentions). These dimensions correspond closely with the three aspects of EDI embeddedness (Chatfield and Yetton, 2000) and suggest that the level of inter-organisational alignment may also be of importance in determining value from $\mathrm{B} 2 \mathrm{~B}$ e-commerce.

Taking the supplier's (or spoke's) perspective in the retail industry, Subramani (2002) considers two different and complementary perspectives on IT use in interorganisational systems:

- transaction processing (or know how), and

- learning and expertise creation (or know what).

Results suggest that a powerful customer is able to appropriate the benefits from the transaction processing resource, but if the supplier creates new knowledge relevant to the relationship with the customer, benefits from this are retained by the supplier.

14 EDI system integration at both initiator and adopting firms. 


\subsection{Research propositions}

Drawing the above threads together, benefits from B2B e-commerce tend to be generated and appropriated when the aim is to create of knowledge. This, in turn is enabled by high inter-organisational embeddedness or alignment. Given the prior literature about the benefits of intra-organisational alignment, we propose that two dimensions are important: (1) achieving alignment between business strategy and IT strategy (Henderson and Venkatraman, 1999); and (2) achieving fit between a firm's strategy, organizational structure, and its processes (see for example Chandler, 1962; Brynjolfsson, Renshaw and van Alstyne, 1997; Porter, 1996, 2001).

We define high-level B2B e-commerce alignment with a scope that includes the IT and business strategies, infrastructure and processes of both the initiator (customer) and adopter (supplier) firms (Figure 1). For the supplier to create benefits, its IT and business strategies need to be aligned and the infrastructure and processes need to realize (or fit) their respective strategies. Within the adopter's IT strategy, there attention to technology scope, IT governance and systemic competencies; while within IT infrastructure and processes, the operational architecture, processes and skills realize the IT strategy effectively (Figure 2). (Definitions for the components of IT strategy and IT infrastructure and processes are provided in Table 1). Low-level inter-organizational strategic alignment differs from high-level alignment by a weakening of most of the alignment and realization dimensions of the high alignment scenario (Figure 3).

On the basis of this discussion, we set forth the following research propositions:

Research Propositions $1 a$ and $1 b$ :

Suppliers that adopt $B 2 B$ e-commerce reactively as a result of the exercise of customer power exhibit lower levels of B2B e-commerce alignment.

Suppliers that adopt $B 2 B$ e-commerce as a result of an internal proactive decision exhibit higher levels of B2B e-commerce alignment.

Research Proposition 2:

Suppliers that have achieved higher levels of B2B e-commerce alignment are better placed to create and appropriate benefits. 


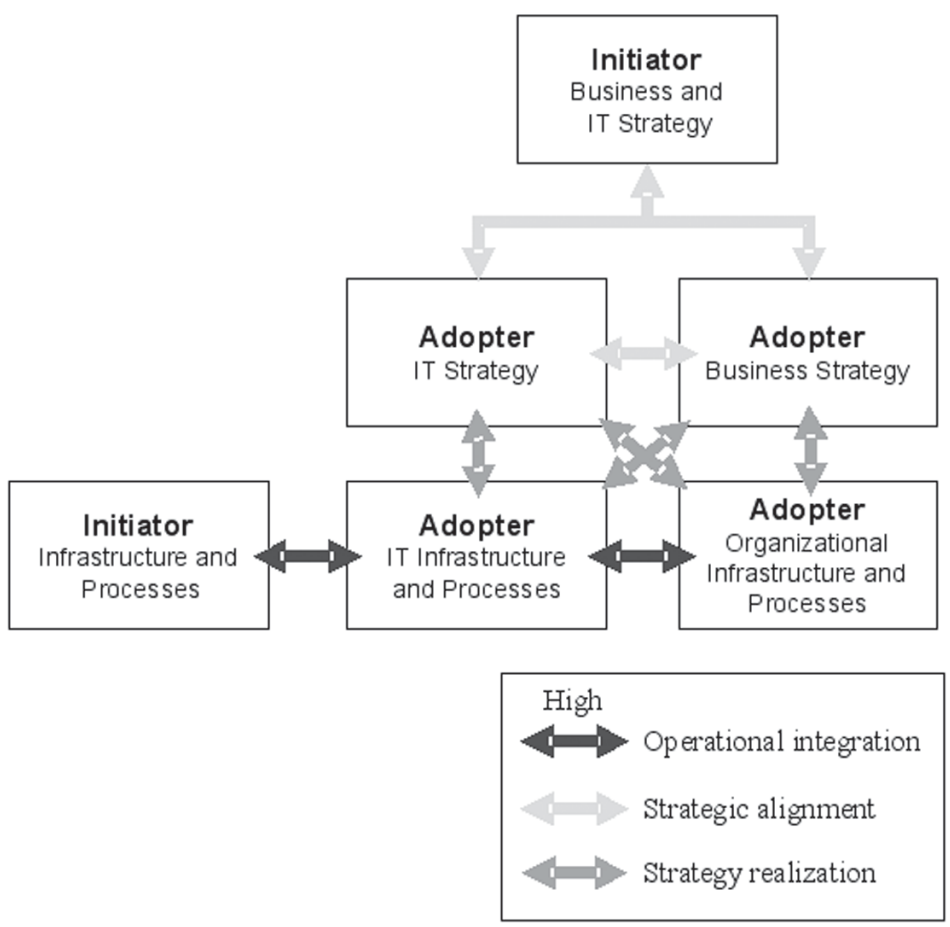

Figure 1. High-level B2B e-commerce alignment

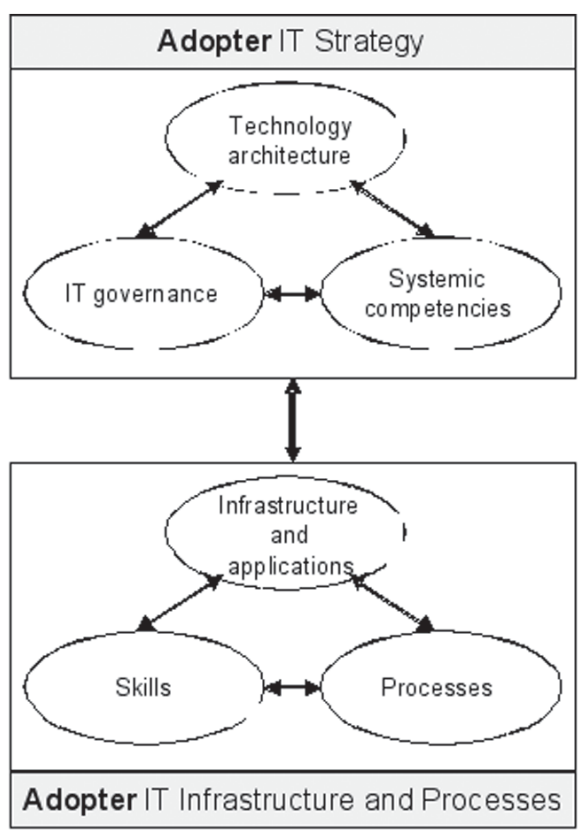

Figure 2. Intra-organizational strategic alignment in the IT domain 


\begin{tabular}{|l|l|}
\hline Component & Definition \\
\hline $\begin{array}{l}\text { Technology } \\
\text { architecture }\end{array}$ & $\begin{array}{l}\text { Choices that pertain to information technologies and their inter-relationship that } \\
\text { support the business strategy. e.g. internal business systems together with EDI, } \\
\text { Web-based applications, AANX, and/or Covisint. }\end{array}$ \\
\hline TT governance & $\begin{array}{l}\text { Mechanisms for obtaining the required IT competencies, internally or through the } \\
\text { formation of strategic alliances, joint ventures with IT vendors. }\end{array}$ \\
\hline $\begin{array}{l}\text { Systemic } \\
\text { competencies }\end{array}$ & $\begin{array}{l}\text { The attributes (or operational excellence measures) for dem onstrating how IT } \\
\text { supports the business strategy. e.g. system reliability, interconnectivity fl exibility. }\end{array}$ \\
\hline Processes & $\begin{array}{l}\text { The work processes that are central to the operations of the business information } \\
\text { systems. e.g. monitoring, control, development. }\end{array}$ \\
\hline Skills & $\begin{array}{l}\text { The skills required to effectively manage and operate the information systems } \\
\text { infrastructure. }\end{array}$ \\
\hline $\begin{array}{l}\text { Infrastructure and } \\
\text { applications }\end{array}$ & $\begin{array}{l}\text { The configuration of hardware, software, communication, and data; and the } \\
\text { portfolio of applications. }\end{array}$ \\
\hline
\end{tabular}

Table 1. Definitions for the components of IT strategy and IT infrastructure and processes (based on Henderson and Venkatraman, 1999) $)^{15}$

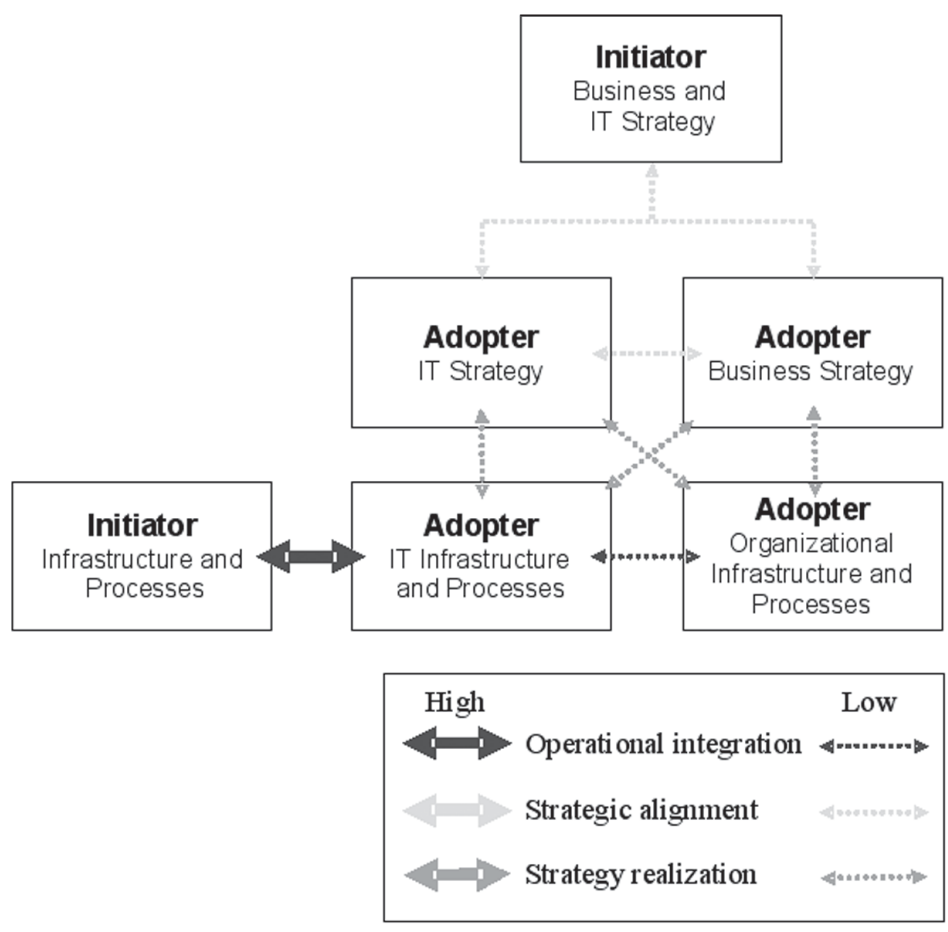

Figure 3. Low-level B2B e-commerce alignment

15 Some of the headings have been renamed compared with the original source. The definitions aim to be faithful to the source, with examples added relevant to the domain of e-commerce in the automotive industry. 


\section{RESEARCH METHOD}

A multiple-case study approach was selected in this research to support the primary objective of probing issues related to the level of B2B e-commerce alignment and its association with benefits. Because the research is largely exploratory and explanatory in nature, designed to extend earlier conceptual work (e.g., Reekers and Smithson, 1996; Tuunainen, 1998; Chatfield and Yetton, 2000), the theory and explanation-building approach from case study research depicted by Yin (1994) and Eisenhardt (1989) was followed. The automotive industry was selected for this case study research because there is a long history of EDI adoption following iniation by the OEMs.

\subsection{Automotive industry}

A long-term trend in the automotive industry is for the OEMs to outsource component production. As evidenced by the 3DayCar programme ${ }^{16}$, there has been a trend towards shorter lead times during the 1990s, with a vision for a 3day cycle from order placement to delivery. A briefing paper from the 3DayCar programme ${ }^{17}$ highlights trends towards EDI and web-based information exchange amongst vehicle makers and suppliers, but also notes numerous barriers that arise from current IT systems and confusion about future trends.

Australia's automotive industry is relatively small in a global context. However, its size is broadly comparable with many manufacturing bases outside the USA, Western Europe and Japan, which makes the results of interest to many countries with medium-sized automotive industries.

The OEMs in Australia are part of large multinational companies which have initiated the widespread adoption of EDI. More recently, the automotive industry has received support for the development of infrastructure for B2B e-commerce through the Australian Automotive Network Exchange (AANX) ${ }^{18}$, following similar automotive exchanges in other countries. However, amongst tier 1 suppliers to the automotive manufacturing industry there is only limited adoption of AANX or other B2B e-commerce initiatives. This provides the opportunity for suppliers to include B2B e-commerce within their strategic thinking.

16 http://www.3daycar.com/, accessed on 14 January 2003.

17 “Current IT Systems: The Barriers to 3DayCar”, http://www.3daycar.com/ accessed on 15 January 2003.

18 http://www.motor.net.au/AANX/ 


\subsection{Experimental procedure}

The data gathering and analysis procedure was divided into the following steps. First, the research propositions were specified as precisely as possible, as set forth above. Second, the specification of the population was chosen to control industry effects by the selection of the automotive industry and by a focus on tier 1 suppliers. The sampling logic followed literal replication (cases selected so that they predict similar results) and theoretical replication (cases predicting contrary results to some extent but for predictable reasons) (Yin, 1994).

\begin{tabular}{|l|c|c|l|}
\hline \multirow{2}{*}{ Firm } & \multirow{2}{*}{ Type } & \multicolumn{2}{|c|}{ Informants } \\
\cline { 3 - 5 } & & No. & Positions (Australian unless noted otherwise) \\
\hline Supplier S1 & M, P & 3 & CEO, Director of Op erations, IS Manager \\
\hline Supplier S2 & M, P & 3 & $\begin{array}{l}\text { Deputy CEO and Director of Operations, GM Logistics, IS } \\
\text { Manager }\end{array}$ \\
\hline Supplier S3 & M, P & 3 & Asia Pacific CEO, IS Manager, Global IS Manager \\
\hline Supplier S4 & A, P & 1 & Managing Director \\
\hline Supplier S5 & A, L & 1 & IT Manager \\
\hline OEM & M, L & 2 & Manager IS (ERP), Manager IS (Web and e-commerce) \\
\hline Logistics firm & M, L & 1 & General manager \\
\hline
\end{tabular}

$\mathbf{M}=$ multinacional, $\mathbf{A}=$ Australian, $\mathbf{P}=$ privately owned, $\mathbf{L}=$ listed

Table 2. Data collection sources

A consultant with extensive experience in the automotive industry provided advice about firms to include in this study given these guidelines, with replication being driven by different sizes and ownership structures of supplier firms. A crosssectional qualitative analysis was conducted on seven companies involved in the automotive industry: five tier 1 suppliers, one OEM and one logistics firm (see Table 2). For confidentiality reasons, firms in this research are referred to by number rather than by name. Altogether, three interviewers conducted 13 interviews with executives from the case companies using a script of structured open-ended questions. We aimed to interview the managing director or CEO and the senior operations and IT executives because these were viewed as "key informants" in our investigation (Yin, 1994). In practice this was not always possible. Data collection was carried out between July and December 2002. 
The consultant provided extensive comments during the development of the interview guide, which was based on conceptualisations provided by the prior literature and the primary objectives of the investigation. The interview script was in six parts and the following information was collected: (1) Profile of the firm; (2) professional role of interviewee; (3) business strategy of the firm; (4) IT infrastructure and processes of the firm; (5) IT strategy of the firm; and (6) summary and conclusion of the interview.

The interviews were of forty-five to ninety minutes in duration and followed the same predetermined structure. Broad items were used to minimize leading questions and to capture variation in the interviewees' answers. The interviews were performed in an atmosphere of trust where certain confidential issues were discussed and in some cases confidential documents were received. All interviews were tape recorded and transcribed. The manuscript for each interview was checked for errors and then coded. "Open coding" (Miles and Huberman, 1994), an iterative process that allows for comparisons among case studies, was used to summarize segments of the data. For example, one comparison that was essential for this investigation was to examine inter-organizational alignment and to compare similarities and differences among the case studies. Coding was conducted over several weeks and each manuscript's coding scheme was checked independently by at least two members of the research team. The NVivo ${ }^{19}$ computer package assisted in the analysis of the interviews.

\section{RESULTS}

\subsection{Research propositions $1 \mathrm{a}$ and $1 \mathrm{~b}$}

Of the five tier 1 supplier firms interviewed, four stated that they adopted B2B e-commerce as a direct result of the exercise of customer power. For example, the $\mathrm{CEO}$ of a tier 1 supplier illustrated this point in the following manner: "We are driven by the IT requirements of these very large customers ... [we're] advised that you'll have those facilities operational yesterday or you don't get any forward orders. You will not participate in the next model. You put the facilities in or you die" (S1), while the Deputy CEO and Director of Operations of another multinational supplier outlined the influence of customer power in a similar manner: "Very much so. An example would be on the spare parts side of the business where both [large OEMS] have announced that they'll be using ... an internet-based system for ordering of spare parts in the future. So they're dictating the pace in terms of the use of technology in that process" (S2).

\footnotetext{
19 http://www.qsr.com.au/products/nvivo.html
} 
However, one supplier discussed a two-way process where not only customers influence suppliers, but suppliers can influence the OEMs and their own suppliers. The Asia Pacific CEO of this supplier elaborates: "Yes absolutely. I think to some degree customers have said we want real time information on our supply time ... [but] on the other hand, I think there's people like ourselves who will influence the customers. For instance I mean we were one of the first people who go into real just in time with [large OEM] because we had some supply problems ... [and] we demand it from our suppliers ... So yes, we influence the suppliers [and customers] in that sense" (S3).

All suppliers exchange information electronically with vehicle manufacturers using EDI and to a lesser or greater degree integrate this with their own enterprise systems to enhance the speed of information flow and decision-making. But this integration does not necessarily reflect inter-organizational strategic alignment. For example, as one General Manager of Logistics explains: "I think the business strategy was formulated almost mutually exclusive to the IT strategy. Totally separate from what I can gather. Yeah. There wasn't really an integrated approach" (S2). Even though most suppliers stated that their IT strategy was aligned with the firm's business strategy, this perception does not necessarily indicate strategic alignment. As the CEO of a supplier illustrates: "IT's contribution is pivotal ... and one of the reasons it's pivotal is that it's powerful if you use it correctly, very powerful. It can save money on the one hand and it can extend customer servicing on the other. And we see it as a key strategic aspect of the business. But again as a tool rather than as an end in itself" (S1).

In the context of the strategic alignment model in Figure 1, tier 1 suppliers view IT as a function that mainly provides support to the business and does not generate strategic direction for the business. The external influence of the OEMs and some internal initiatives impinge directly on IT infrastructure and processes. However, most of these firms have IT staff and processes that aim to integrate information to further exploit its utility. Meanwhile, S3 provides evidence that proactive firms do not wait for influence from external stakeholders, but rather seek to mutually influence the external stakeholders themselves: "I think that [IT] is an enabling tool to facilitate business" (S3). As such there is a low-level of IT strategy in most of the supplier firms, with the exception of S3 that operates under the provisions of a global IT policy. This conclusion is supported by the typical organisational structure of suppliers where the IT manager reports to a finance executive, and IT does not have a separate position in the firm's executive group. One consequence of this is that: “...a [network-related] decision that I can't really share with anybody because management don't know what I'm talking about" (IT manager at S5). 
While insights about the value of integration were evident (for example: "...the only problem I would see is that we're not integrated enough electronically ..." (S2)), this integration was not necessarily translated into strategic advantage. However, S3 was an exception and took integration one step further in several comments about progressing IT initiatives: “...the demand comes internally. So from the business managers, they suggest areas with suppliers or customers that could be improved, but they're the ones that actually drive the change". An informant from S3 also suggested that the OEMs are lagging behind and they would prefer to work proactively with them to improve IT processes and infrastructures. S3 was the only supplier in the sample that mentioned a global intra-organizational IT policy that covers certain hardware and software standards or products, together with a compliance process.

An issue that is evident amongst tier 1 suppliers is the publishing of information by the OEMs on web portals or extranets. The tier 1 suppliers are expected to log into the extranet and access information that is relevant about meetings and some aspects of their trading relationship. Such an arrangement clearly weakens B2B e-commerce because an extranet does not provide for immediate electronic integration of information, and is another exercise of customer power. This may be one of the clearest symptoms of the evident low-level inter-organizational alignment in Australia and is evidenced by the following description of the problem: "With the Internet each [OEM has] got their own environment that they want you to go into and do whatever they want you to do, [so we've got] different systems in place for every customer that we have. So it becomes a bit of a challenge trying to create them. And some of them can't be integrated at this point. For instance, the [OEM] supplier-network has all their stats on [the Internet], their fliers, all their reject status and other documentation schedules. You can't get the information off the air to make use of it, which is a real problem. With EDI it just feeds straight in, straight through. It's on a standard format" (IS Manager, S1). A similar account of the problem is provided by the general manager of logistics, S2: "EDI is becoming almost old hat. Now that everything is internet based. So we're still trying to get the EDI up and running. The day we finish and have completely EDI 100\% integration and raise our hands in the air, they'll [OEMs] say well you're outdated now. It's on the Internet ... Now a lot of our customers will just do what we used to do with our after market customers and that is manually just key in our data. What we want to do is electronically download our data and supply it electronically".

Another problem that was widely raised by suppliers is the different software packages and file exchange formats used by the different vehicle makers for engineering design information. This appears to be an instance where the OEMs are adopting global firm-wide policies. In a small market like Australia where 
suppliers typically trade with three or four OEMs, this adds considerable costs to the suppliers. However, some of the multi-national suppliers discussed the potential for round-the-clock design work as design effort followed the sun around the world, facilitated by electronic exchange of design information. But no detailed plans were revealed by our interviews for implementation in the short term.

An upcoming development, mentioned by the OEM, may be the provision of electronic information for suppliers using web services, rather than using HTML on an extranet. This would have the potential to provide for broader and richer types of information exchange using XML as the base standard. None of the suppliers mentioned this possibility when asked about their plans for extending the scope of electronic information exchange.

In general, research propositions $1 \mathrm{a}$ and $1 \mathrm{~b}$ are supported. Based on an analysis of the transcripts of discussions with the five tier 1 suppliers, most supplier firms emerge as exhibiting lower-levels of inter-organizational strategic alignment whereas $\mathrm{S} 3$ emerges as distinctive. The CEO leads by example: "I want to be able to walk up to any computer of any [company in the group] in the world, dial in and then just be able to get all of my information, my mail...", "...speed of information and the accuracy of that information is a huge competitive advantage." (S3). A more speculative attitude to IT investment is evident, in drawing and analogy with R\&D expenditure: "you know you've got to take a risk sometimes ... and you win one big one." (S3). However, at the regional level: "in our strategic planning we don't mention IT in the sense of it is a particular strategy but comes back to my initial statement, what is IT, its an enabling tool and its just part of it" (S3).

\subsection{Research proposition 2}

Prior research suggests that inter-organisational strategic alignment provides numerous strategic benefits to the firm. These strategic benefits are confirmed by our research, albeit by one firm, as illustrated by the CEO of S3: "In today's marketplace particularly, the speed of information and the accuracy of that information is a huge competitive advantage. And I think in our organization we've done a reasonably good job of integrating all of that. Everything from business systems, to marketing systems, to supply systems, and having that available in real time. I don't know how much value you can put on it but I think it's [an] absolute necessity today and without it, I don't know how we [would] survive. I really don't. It's ... an imperative ... to have high speed, high volume, accurate, integrated, standardised information available to me ... I can't think how you'd managed your business today without it." 
Moreover time-based competitive advantage is an important strategy used in the automobile industry and our research reveals that only S3 was able to utilise this approach effectively, as reflected by the following comment from the IT Manager: "Speed's [imperative] ... if we were talking five years ago, we'd [have] said it was standardisation, but that doesn't ... count ... it's the speed of reacting to things. If you're not fast you're dead basically. If you can't get things moving in a reasonable amount of time, you struggle to get anything in place in time. Our project times are getting shorter. It used to be five years for a project for a new car. It's now down, I think the latest one [for large OEM] was 18 months, so it's really shrinking. So you have to have that speed of turnover of getting things out ... so speeds the biggest advantage."

However, while the other four suppliers generally believed that there were strategic advantages to inter-organisational alignment, they were unable to demonstrate whether their organisations had achieved inter-organisational alignment and what the benefits of this alignment are. For example, most suppliers focused on benefits that led to operational efficiency, but failed to highlight any attention to knowledge creation. For example, the General Manager of Logistics at S2 reflects this sentiment in the following manner: "IT can play an important role in being part of the competitive edge. Because ... [IT] allows us to become efficient in production, we can do it at a much lower cost [and] if we can identify where our problems in inefficiencies are ... that is the role of IT in the organisation."

Thus based on our analysis of the transcripts of discussions with the five tier 1 suppliers, only one supplier firm was able to outline the strategic benefits of inter-organisational alignment, that is, "It helps [in] the globalisation of the business ... assists in the management of all [facets] of the business ... and assists in real time information, which is of strategic importance to us" (CEO, S3). As such, research proposition 2 is supported by our research.

\section{IMPLICATIONS FOR PRACTICE}

Recently, the Australian government has inquired into the automotive industry in an effort to sustain its competitive position on a global scale. This research is directly relevant to one aspect of the recent Government Productivity Commission inquiry: the assessment of "the interdependence between vehicle assemblers and component producers" 20 .

20 http://www.pc.gov.au/inquiry/auto/index.html, accessed on 14 May 2002. 
The impetus for IT adoption in the automotive industry is largely left to the discretion of the OEMs. The five suppliers interviewed in this research perceive that the OEMs influence the choices over methods for information exchange, but most feel there is latitude for negotiation over details and timing. S3 in particular perceived that the OEMs are receptive to suggestions, that they synthesize the best suggestions and exploit them in the industry. The OEM itself expressed a clear policy not to endorse any particular software vendor, and expressed reluctance to be seen to mandate any particular technology or standard, in case its lifetime provided short and the mandate became unsustainable.

The automotive exchanges such as AANX ${ }^{21}$, and Covisint ${ }^{22}$ globally, that arise from automotive federations or joint ventures, are a further potential influence on suppliers. There is a perception amongst suppliers that the vehicle makers support adoption of AANX, and its perceived benefits are to provide relatively cheaper EDI connectivity and sufficient bandwidth for exchanging engineering information. There is also a continuing debate and tension between the vehicle makers' proprietary networks and information resources versus AANX.

The specialist logistics firms are also emerging as important stakeholders in the automotive industry. These firms have sophisticated software to integrate global supply chain execution and management by linking the physical shipping of inventory with electronic information about that inventory, thus providing track and trace of inventory in real time. They also create knowledge, for example tailored management reports concerning supplier performance. Some logistics providers are also engaged in final sub-assembly of components from suppliers prior to delivery to OEMs, which can further strengthen their importance to the industry.

In the future, Web services and BizDex ${ }^{23}$, a proof-of-concept compatible with ebXML (Kotok and Webber, 2002), are likely to be available at relatively low cost over the Internet once critical mass and a suitable security regime is established. Such Web services and the logistics firms may diminish the business case from specialized network exchanges like AANX.

\footnotetext{
${ }^{21}$ http://www.motor.net.au/aanx/, accessed on 14 January 2003.

${ }^{22} \mathrm{http} / / / \mathrm{www} . c 0 v i s i n t . c o m$, accessed on 14 January 2003. In Australia, Covisint has not being strongly backed after an initial push towards adoption. It is seen as a largely web-based resource and only one supplier included in this research is a member. The level of adoption is similar to that reported in Europe by Arbin and Essler (2002).

${ }^{23}$ http://www.bizdex.com.au
} 


\section{CONCLUSIONS AND LIMITATIONS}

The results of the research in this study indicate that tier 1 suppliers in the automotive industry in Australia have, at least to some degree, attempted to make changes to their IT infrastructure and processes to accommodate the requirements of electronic information interchange with major customers. On the other hand, it was clear that the role of IT was often limited and not viewed as core to business. This was reinforced by the supplier firms generally exhibiting a relatively weak IT strategy and therefore a low-level of B2B e-commerce alignment.

Given that time-based competitive advantage is important (Chatfield and Yetton, 2000), and relies on systemic competencies in IT strategy; it would appear that more attention to IT strategy and subsequent alignment is warranted. The logistics firms are demonstrating the power of electronic information to create new knowledge that is relevant to their customers. Consistent with the findings of Chatfield and Yetton (2000), it is likely that customer power is being inappropriately applied and suppliers need to be more proactive. This lack of genuine partnership is perhaps best illustrated by the OEMs publishing critical information on Web portals and relying on the suppliers to extract the information potentially in non-electronic format to be re-typed into their own information systems. This requires no negotiation with the suppliers, but also sustains lowlevel integration that most likely is a cost adopted by the industry in the long term.

While Australia's automotive industry is relatively small on a worldwide basis, its size is comparable with the automotive industry in many countries which should make the results of interest internationally.

There are several limitations of this study. First, a case study research method was used, and consequently, the limitations associated with the case study approach are applicable (Yin, 1994). Second, a convenience sampling procedure was used, but on sound advice from a knowledgeable consultant to the industry. Third, the number of firms was limited, although the five suppliers are representative of approximately 200 suppliers in Australia, the majority of which very small firms and are outside the scope of this study.

Several avenues for future research result from this study. While the research findings provide evidence on the changes made to IT infrastructure by a limited number spoke firms in response to requirements from hub firms in the automotive industry in Australia, a survey that covers the majority of spoke firms would be valuable to gain a better understanding as to whether the results hold across the whole industry. Second, future research on other industries where similar 
requirements of hub firms of spoke firms would provide evidence across industry settings. Third, the emergence of web services, the availability of a wider range of electronic modes and the software provided by logistics firms will no doubt require future study into changes to $\mathrm{B} 2 \mathrm{~B}$ e-commerce alignment.

\section{REFERENCES}

ARBIN, K.; ESSLER, U. (2002): "Emerging Industrial eMarkets: The Case of Covisint in Europe", 15th Bled Electronic Commerce Conference, Bled, Slovenia, June 17-19, 2002.

BARBER, N. F. (1991): "Hubs and spokes", EDI Worlds, vol. 1, no. 11: 6-9.

BARNEY, J. (1991): "Firm resources and sustained competitive advantage", Journal of Management, vol. 17, no. 1: 99-120.

BARNEY, J. (2001): "Resource-based theories of competitive advantage: A tenyear retrospective on the resource-based view", Journal of Management, vol. 27: 643-650.

BERGERON, F.; RAYMOND, L. (1997): "Managing EDI for corporate advantage: A longitudinal study", Information Management, vol. 31, no. 6: 319-333.

BRYNJOLFSSON, E.; RENSHAW, A.; VAN ALSTYNE, M. (1997): "The matrix of change", Sloan Management Review, Winter: 37-54.

BURGERS, W.P.; HILL, C.W.; KIM, W.C. (1993): "A theory of global strategic alliances: The case of the global auto industry", Strategic Management Journal, vol. 14, no. 6: 419-432.

CHAN, Y.; HUFF, S.; BARCLAY, D.W. (1997): "Business strategic orientation, information systems strategic orientation, and strategic alignment", Information Systems Research, vol. 8, no. 2: 125-150.

CHANDLER, A. (1962): Strategy and Structure: Chapters in the History of the Industrial Enterprise. Cambridge. MA. MIT Press.

CHATFIELD, A.T.; YETTON, P. (2000): "Strategic payoff from EDI as a function of EDI embeddedness", Journal of Management Information Systems, vol. 16, no. 4: 195-224.

CLEMONS, E.; ROW M. (1991): "Sustaining IT advantage: The role of structural differences”, MIS Quarterly, Sept: 275-292. 
CLEMONS, E.; ROW M. (1992): "Information technology and industrial cooperation: The changing economics of coordination and ownership", Journal of Management Information Systems, vol. 9: 9-28.

CRAGG, P.; KING, M.; HUSSIN H. (2002): "IT alignment and firm performance in small manufacturing firms", Strategic Information Systems, vol. 11: 109-132.

DAS, T. K.; TENG, B-S. (2000): "A Resource-Based theory of Strategic Alliances", Journal of Management, vol. 26, no. 1: 31-61.

DIERICKX, I.; COOL, K. (1989): “Asset stock accumulation and sustainability of competitive advantage"; Management Science, vol. 35: 1505-1511.

DEN HENGST, M.; SOL, H. G. (2002): "The Impact of Electronic Commerce on Interorganizational Coordination: A Framework from Theory Applied to the Container-Transport Industry", International Journal of Electronic Commerce, vol. 6, no. 4: 73-91.

DYER, J.H. (1997): "Effective inter-firm collaboration: How firms minimize transaction costs and maximize transaction value", Strategic Management Journal, vol. 18 , no. 7 : 535-556.

EISENHARDT, K. M. (1989): "Building theories from case study research", Academy of Management Review, vol. 14, no. 4: 532-550.

GEBAUER, J.; SHAW, M. J. (2002): "Introduction to the special section: Businessto-business electronic commerce", International Journal of Electronic Commerce, vol. 6 , no. 4: 7-17.

GRANT, R.M. (1991): “The resource-based theory of competitive advantage: Implications for strategy formulation", California Management Review, Spring: 114-135.

HART, P. J.; SAUNDERS, C. S. (1998): "Emerging electronic partnerships: Antecedents and dimensions of EDI use from the supplier's perspective", Journal of Management Information Systems, vol. 14, no. 4: 87-111.

HENDERSON, J. C.; VENKATRAMAN, N. (1993): "Strategic alignment: Leveraging information technology for transforming organizations", IBM Systems Journal, vol. 32, no. 1: 4-16.

HENDERSON, J. C.; VENKATRAMAN, N. (1999): "Strategic alignment: Leveraging information technology for transforming organizations", IBM Systems Journal, vol. 38, nos. 2 and 3: 472-484. 
ISKANDAR. B. Y.; KUROKAWA, S.; LEBLANC, L. J. (2001): "Business-tobusiness electronic commerce from first- and second-tier automotive suppliers' perspectives: A preliminary analysis for hypothesis generation", Technovation, vol. 21: 719-731.

JOSHI, A.; STUMP, R. (1999): “The contingent effect of specific asset investments on joint action in manufacturer-supplier relationships: An empirical test of the moderating role of reciprocal asset investments, uncertainty, and trust." Academy of Marketing Science Journal, vol. 27: 291-305.

KHANANCHI, D.; SUTTON, S. G. (2000): “Assurance Services for Businessto-Business Electronic Commerce: A Framework and Implications", Journal of the Association for Information Systems, vol. 1, article 11.

KOTOK, A.; WEBBER, D. R. R. (2002): ebXML: The New Global Standard for doing Business over the Internet. New Riders. Pearson.

LAUER, T.W. (2000): "Side effects of mandatory EDI order processing in the automotive supply chain”, Business Process Management Journal, vol. 6, no. 5, 366-375.

LEE, H. G.; CLARK, T.; TAM, K. Y. (1999): “Can EDI Benefit Adopters?”, Information Systems Research, vol. 10, no. 2: 186-195.

MASSETI, B.; ZMUD, R. W. (1996): "Measuring the extent of EDI usage in complex organizations: strategies and illustrative examples", MIS Quarterly, vol. 20, no. 3: 331-345.

MILES, M. B.; HUBERMAN, A. M. (1994) Qualitative Data Analysis. Thousand Oaks, CA. Sage Publications.

MILES, R. E.; SNOW, C. C. (1978): Organizational Strategy Structure and Process. McGraw-Hill. New York.

MILLER, D. (1987): "Strategy making and structure: Analysis and implications for performance”, Academy of Management Journal, vol. 30, no. 1: 7-32.

MILLER, D.; TOULOUSE, J.M. (1986): "Chief executive personality and corporate strategy and structure in small firms", Management Science, vol. 32, no. 11: 1389-1409.

MUKHOPADHYAY, T.; KEKRE, S.; KALATHUR, S. (1995): "Business value of information technology: A study of electronic data interchange", MIS Quarterly,vol. 19, no. 2: 137-156. 
PAPP, R. (1999): "Business-IT alignment: productivity paradox payoff?", Industrial Management and Data Systems, vol. 99, no. 8: 367.

PARK, N. K.; MEZIAS J. M.; SONG, J. (2003): "A Resource-based View of Strategic Alliances and Firm Value in the Electronic Marketplace", Journal of Management, forthcoming.

PARNELL, J.; WRIGHT, P.; TU, H. S. (1996): “Beyond the strategy-performance linkage: The impact of strategy-organizational-environment fit on business performance", American Business Review, vol. 14, no. 2: 41-50.

PORTER, M. E. (1990): Competitive Advantage. New York. The Free Press.

PORTER, M. E. (1996): “What is Strategy?", Harvard Business Review, vol. 76, no. 6: 61-77.

PORTER, M. E. (2001): "Strategy and the Internet", Harvard Business Review, March: 63-78.

PRAHALAD, C.K.; HAMEL, G. (1990): "The core competence of the corporation", Harvard Business Review, vol. 68, no. 3: 78-91.

PREMKUMAR, G.; RAMAMURTHY, K.; CRUM, M. (1997): "Determinants of EDI adoption in the transportation industry", European Journal of Information Systems, vol. 6: 107-121.

PREMKUMAR, G.; RAMAMURTHY, K. (1995): “The Role of Interorganizational and Organizational Factors on the Decision Mode for Adoption of Interorganizational Systems", Decision Sciences, vol. 26, no. 3: 303-336.

REEKERS, N.; SMITHSON, S. (1996): "The role of EDI in inter-organization coordination in the European automotive industry", European Journal of Information System, vol. 5: 120-130.

RIGGINS, F.; MUKHOPADHYAY, T. (1994): "Interdependent benefits from interorganizational systems: Opportunities for business partner reengineering", Journal of Management Information Systems, vol. 11, no. 2: 37-57.

ROBINS, J.A. (1987): "Organizational economics: Notes on the use of transaction cost theory in the study of organizations", Administrative Science Quarterly, vol. 32: $68-86$.

SCOTT MORTON, M., ed. (1991): The Corporation of the 1990s: Information Technology and Organizational Transformation. New York. Oxford University Press. 
SRIRAM, R. S.; ARUNACHALAM, V.; IVANCEVICH, D. M. (2000): "EDI Adoption and Implementation: An Examination of Perceived Operational and Strategic Benefits, and Controls", Journal of Information Systems, vol. 14, no. 1: $37-52$.

SUBRAMANI, M. R. (2002): "How do suppliers benefit from IT use in supply chain relationships?" MIS Research Center Working Paper \#02-14, Carlson School of Management, University of Minnesota.

SUBRAMANI, M. R.; VENKATRAMAN, N. (2003): "Safeguarding investments in asymmetric interorganizational relationships: Theory and evidence", Academy of Management Journal, vol. 46, no. 1: 46-62.

SWATMAN, P. M. C.; SWATMAN, P. A.; FOWLER, D. C. (1994): "A model of EDI integration and strategic business reengineering", The Journal of Strategic Information Systems, vol. 3, no. 1: 41-60.

TALLON, P. P.; KRAEMER, K. L. (2003): "Investigating the Relationship between Strategic Alignment and IT Business Value: The Discovery of a Paradox", In N. SHIN (ed.) Creating Business Value with Information Technology: Challenges and Solutions. Idea Group Publishing. Hershey.

TEO, T. S.; KING, W. R. (1996): "Assessing the impact of integrating business planning and IS planning", Information \& Management, vol. 30, no. 6: 309-321.

TUUNAINEN, V. K. (1998): "Opportunities of effective integration of EDI form small businesses in the automotive industry", Information \& Management, vol. 34: 361-375.

ULRICH, D.; LAKE, D. (1991). Organizational Capability. New York. Wiley

VENKATRAMAN, N. (1989): "Strategic orientation of business enterprises: The construct dimensionally and measurement", Management Science, vol. 35, no. 8: 942-962.

WALTON, S.; GUPTA, J. (1999): "Electronic data interchange for process change in an integrated supply chain", International Journal of Operations and Production Management, vol. 19: 123-134.

WILLIAMSON, O.E. (1981): "The economics of organization: Origin, evolution, attributes", Journal of Economic Literature, vol. 19: 1537-1568.

WILLIAMSON, O.E. (1985): The Economic Institutions of Capitalism: Firms, Markets, Relational Contracting. New York. Free Press. 
YIN, R. K. (1994): Case Study Research: Design and Methods ( $2^{\text {nd }}$ Edition). Newbury Park, CA. Sage Publications.

ZAHRA, S.; COVIN, J. (1993): "Business strategy, technology policy and firm performance”, Strategic Management Journal, vol. 14, no. 3: 451-478.

ZAHEER, A.; VENKATRAMAN, N. (1994): "Determinants of electronic integration in the insurance industry: An empirical test", Management Science, vol. 40, no. 5: 549-566. 